\title{
Dasar Pelaksanaan Dokumentasi Keperawatan Di Rumah Sakit
}

\author{
Putri Meiyarny Zega \\ putrimeivarny@gmail.com
}

\section{LATAR BELAKANG}

Pendokumentasian keperawatan akhir-akhir ini disadari merupakan bagian tidak terpisahkan dari perkembangan profesionalisme tenaga keperawatan dari berbagai tatanan pelayanan. Pendokumentasian juga merupakan cermin fisik kemampuan tenaga keperawatan yang bekerja di suatu sistem pelayanan kesehatan. Dokumentasi keperawatan sangatlah penting, akan tetapi pada kenyataannya masih banyak perawat yang kurang mengetahui dokumentasi keperawatan yang baik dan benar.

Dokumentasi keperawatan mempunyai makna penting dalam aspek hukum, kualitas pelayanan, komunikasi, pendidikan, penelitian, dan akreditasi. Berkaitan dengan perlindungan hukum, dokumentasi asuhan keperawatan dapat memberi bukti yang berharga tentang kondisi pasien dan pengobatannya dan dapat bersifat kritis dalam menentukan standar perawatan apakah telah dipenuhi atau tidak (Nursalam, 2008).

Faktor - faktor yang menghambat pendokumentasian antara lain yaitu kurangnya pemahaman tentang dasar - dasar dokumentasi keperawatan, sehingga penulisan dokumentasi tidak mengacu pada standar yang ditetapkan dan akhirnya dokumentasi keperawatan tidak lengkap, kurangnya kesadaran tentang pentingnya dokumentasi keperawatan, dokumentasi keperawatan tidak dianggap sebagai salah satu faktor penentu kualitas pelayanan keperawatan. Dokumentasi Asuhan Keperawatan merupakan informasi tertulis tentang status dan perkembangan kondisi klien serta semua kegiatan asuhan keperawatan yang dilakukan oleh perawat (Fisbach,1991).

Komponen dokumentasi asuhan keperawatan meliputi komponen isi dokumentasi dan komponen dalam konsep penyusunan dokumentasi. Komponen isi dokumentasi meliputi: pengkajian, diagnosis keperawatan, rencana keperawatan, pelaksanaan tindakan keperawatan, evaluasi, pengesahan (tanda tangan/paraf dan nama terang perawat), dan catatan keperawatan diisi secara lengkap dan jelas, resume keperawatan (catatan : pasien pulang atau meninggal dunia). 


\section{METODE}

Artikel ilmiah ini dibuat dengan menggunakan metode literasi/membaca dan menganalisa kajian dari berbagai sumber atau referensi terkait seperti jurnal, buku teks, dan Ebook 8 tahun terakhir. Artikel ilmiah ini ditulis dengan mengacu pada sumber-sumber terkait yang berfokus pada dasar pelaksanaan dokumentasi keperawatan di rumah sakit.

\section{HASIL}

Hasil analisa yang di dapatkan adalah dokumentasi asuhan keperawatan merupakan bagian dari proses asuhan keperawatan yang dilakukan secara sistematis dengan cara mencatat tahap-tahap proses perawatan yang diberikan kepada pasien. Dokumentasi asuhan keperawatan merupakan catatan penting yang dibuat oleh perawat baik dalam bentuk elektronik maupun manual berupa rangkaian kegiatan yang dikerjakan oleh perawat meliputi lima tahap.

Nursalam (2008) menyebutkan instrument studi dokumentasi penerapan standar asuhan keperawatan di RS menggunakan instrument A dari DEPKES (1995) yang meliputi :

1. Standar I (Pengkajian Keperawatan)

Adalah tahap awal dari proses keperawatan dan merupakan suatu proses yang sistematis dalam pengumpulan data dan berbagai sumber data untuk mengevaluasi dan mengidentifikasi status kesehatan klien (Iyer, 2004).

2. Standar II (Diagnosa Keperawatan)

Perumusan diagnosa keperawatan yang baik harus menggambarkan komponen problem, etiologi, symptom dan sign serta berdasarkan kesenjangan antara status kesehatan normal dengan pola fungsi kebutuhan pasien (Effendy, 1995). Untuk dapat merumuskan diagnosa keperawatan dibutuhkan kemampuan analisis yang tinggi sehingga diperlukan sumber daya manusia yang capable dan mempunyai motifasi kuat untuk maju serta berpandangan maju (futuristic).

3. Standar III (Perencanaan Keperawatan)

Perencanaan merupakan tahap selanjutnya setelah pengkajian dan penentuan diagnosa keperawatan. Perencanaan juga merupakan petunjuk tertulis yang menggambarkan secara tepat mengenai rencana tindakan yang dilakukan terhadap pasien sesuai dengan tingkat kebutuhan berdasarkan diagnosa keperawatan yang muncul. Untuk itu rencana tindakan yang baik tentunya harus berdasarkan pada diagnosa keperawatan yang telah dirurnuskan.

4. Standar IV (Intervensi Keperawatan) 
Pelaksanaan atau tindakan adalah pengelolaan dan perwujudan dari rencana yang telah disusun pada tahap perencanaan. Pada tahap pelaksanaan ini dokumentasi menjadi sangat penting karena merupakan pernyataan dari kegiatan atau aktivitas yang otentik dari perawat. Dokumentasi tentang pasien memberi bukti tindakan mandiri dan kolaboratif yang dilakukan perawat, respon pasien terhadap tindakan keperawatan dan perubahanperubahan yang terjadi, Carrol (1998).

5. Standar V (Evaluasi Keperawatan)

Evaluasi adalah mengkaji respon pasien terhadap tindakan keperawatan yang telah dilakukan oleh perawat dengan mengacu pada standar atau kriteria hasil yang telah ditetapkan pada rumusan tujuan. Terlihat pada status pasien yang telah dikaji bahwa kriteria keherhasilan yang dapat digunakan sebagai dasar evaluasi ini tidak selalu dicantumkan sehingga evaluasi yang diilakukan kurang mengacu pada tujuan.

Dokumentasi keperawatan terdiri dari, yaitu :

1. keterampilan berkomunikasi untuk pengumpulan data dan menciptakan hubungan baik antara perawat dan klien dalam pemecahan masalah klien.

2. dokumentasi proses keperawatan yang merupakan metode pemecahan masalah secara sistimatis sesuai kaidah keperawatan.

3. standar dokumentasi dapat memberi informasi pernyataan kualitas dan kuantitas dokumentasi untuk memperkuat pola pendokumentasian keperawatan.

\section{PEMBAHASAN}

Standar dokumentasi menjadi hal yang penting dalam setiap tindakan keperawatan, namun hal ini tidak disadari oleh perawat. Beberapa hal yang sering menjadi alasan antara lain banyak kegiatan-kegiatan diluar tanggung jawab perawat menjadi beban dan harus dikerjakan oleh tim keperawatan, sistem pencatatan yang diajarkan terlalu sulit dan banyak menyita waktu, tidak semua yang ada di institusi pelayanan memiliki pengetahuan dan kemampuan yang sama untuk membuat dokumentasi keperawatan sesuai standar yang ditetapkan oleh tim pendidikan keperawatan sehingga mereka tidak mau membuatnya.

Tenaga keperawatan yang berasal dari berbagi jenjang pendidikan keperawatan dan dari rentang waktu lulusan yang sangat berbeda tapi mempunyai tugas yang cenderung sama dalam pelayanan klien di ruang rawat inap, serta perawat lebih banyak mengerjakan pekerjaan koordinasi dan pelimpahan wewenang. Kondisi ketidaklengkapan tersebut banyak ditemukan di Puskesmas, Rumah Sakit, maupun Rumah Bersalin. (Martini, 2007). 


\section{Pengertian Dokumentasi Keperawatan}

Potter (2005) mendefenisikan dokumentasi sebagai segala sesuatu yang tercetak atau tertulis yang dapat diandalkan sebagai catatan tentang bukti bagi individu yang berwenang. Dokumentasi keperawatan juga merupakan salah satu bentuk upaya membina dan mempertahankan akontabilitas perawat dan keperawatan. Pelaksanaan dokumentasi proses keperawatan juga sebagai salah satu alat ukur untuk mengetahui, memantau dan menyimpulkan suatu pelayanan asuhan keperawatan yang diselenggarakan di rumah sakit. Dokumentasi keperawatan adalah bukti pencatatan perawat dalam melakukan asuhan keperawatan yang disusun secara sistematis dalam suatu format yg dapat dipertanggung jawabkan secara hukum.

\section{Tujuan Dokumentasi Keperawatan}

Tujuan pendokumentasian keperawatan, antara lain sebagai berikut:

a. Sebagai media untuk mendefinisikan fokus keperawatan bagi klien dan kelompok.

b. Untuk membedakan tanggung gugat perawat dengan anggota tim kesehatan lainnya.

c. Sebagai sarana untuk melakukan evaluasi terhadap tindakan yang telah diberikan kepada klien.

d. Sebagai data yang dibutuhkan secara administratif dan legal formal.

e. Memenuhi persyaratan hukum, akreditasi dan professional.

f. Untuk memberikan data yang berguna dalam bidang pendidikan dan penelitian.

3. Manfaat Dokumentasi Keperawatan

a. Sebagai alat komunikasi

1) Pelaporan. Pelaporan dilakukan oleh perawat utk pendokumentasian secara lisan/tulisan. Contoh : perawat shift pagi yang melaporkan kondisi pasien ke perawat shift berikutnya.

2) Catatan. Catatan ditulis perawat di rekam medis, merupakan info status kesehatan pasien yg berkelanjutan meski dengan status penyakit yang berbeda, hal ini penting digunakan untuk terapi lanjutan pasien. Rekam medis kadang berlaku sampai 5 atau 10 tahun.

3) Konsultasi. Konsultasi dilakukan antar tenaga kesehatan, hal itu dilakukan sebagai kolaborasi untuk kesembuhan pasien. Contoh : seorang perawat yang melakukan konsultasi via telepon ke dokter saat ada kasus kegawatan.

b. Sebagai mekanisme pertanggunggugatan

Sedangkan menurut Nursalam (2008), manfaat dokumentasi asuhan keperawatan menurut beberapa aspek berikut : 
a. Aspek hukum : Dokumentasi keperawatan yang dibuat merupakan aspek legal didepan hukum. Dokumentasi merupakan bukti catatan dari tindakan yang diberikan dan sebagai dasar untuk melindungi pasien, perawat dan institusi.

b. Kualitas pelayanan, komunikasi : Melalui audit keperawatan dokumentasi keperawatan dijadikan alat untuk mengukur dalam membandingkan antara tindakan yang diberikan dengan standar yang dijadikan rujukan. Dengan demikian dapat diketahui apakah dalam bekerja telah sesuai dengan standar yang ditetapkan.

c. Keuangan : Dokumentasi yang baik dan teliti akan menjadi bukti bahwa tindakan telah dilakukan oleh perawat. Dan dengan dokumentasi ini maka besarnya jasa yang diberikan akan diberikan sesuai dengan aturan yang ditetapkan ditempat masingmasing.

d. Pendidikan : Dokumentasi keperawatan dapat dijadikan sebagai rujukan bagi siswasiswa perawat.

e. Penelitian : Penelitian keperawatan dengan menggunkan data-data sekunder akan sangat bergantung dengan kualitas dari dokumentasi keperawatan yang dibuat. Kesalahan dalam membuat atau pengisian dokumentasi yang tidak lengkap akan membuat informasi tentang riwayat pasien menjadi kabur.

\section{Komponen Model Dokumentasi}

a. Keterampilan komunikasi secara tertulis

Komunikasi memungkinkan perawat untuk megkomunikasikan da menjelaskan apa yag sudah, sedang, dan yang akan dikerjakan selanjutnya bila terjadi efektifitas komunikasi. Contoh efektifitas pola penulisan :

1) Menuliskan informasi yang bermakna

2) Mengkominikasikan dengan tenaga kesehatan lainnya

3) Manfaat dan data pasien yang akurat dapat dicatat

4) Kreatifitas dalam melakukan pencatatan dilakukan secara konsisten, pencatatan secara konsisten meliputi : riwayat keperawatan, masalah aktual dan potensial, perencanaan dan tujuan saat sekarang dan yang akan dating, pemeriksaan, pengobatan, promosi kesehatan untuk membantu mencapai tujuan yang telah ditetapkan, dan evaluasi tujuan keperwatan.

b. Keterampilan dokumentasi proses keperawatan

Dokumentasi merupakan bagian integral dari proses, bukan sesuatu yang berbeda dari tindakan, dan evaluasi.

c. Keterampilan standar dokumentasi 
Standar dokumentasi adalah suatu pernyataan tentang kualitas dan kuantitas dokumentasi yang dipertimbangkan dalam situasi tertentu. Standar dokumentasi konsisten, memiliki pola yang efektif, lengkap dan akurat. Merupakan standar yang dapat digunakan untuk memberikan pengarahan dan panduan dalam melakukan dokumentasi proses keperawatan.

Semua tindakan tersebut harus didokumentasikan sebagai bukti penyelenggaraan proses keperawatan. Data klinis yang lengkap dan berkualitas dapat meningkatkan mutu layanan kesehatan. Keengganan klinisi menulis secara lengkap setiap proses penatalaksanaan medis merupakan kendala yang dihadapi.

\section{PENUTUP}

1. Kesimpulan

Dokumentasi asuhan keperawatan merupakan bagian dari proses asuhan keperawatan yang dilakukan secara sistematis dengan cara mencatat tahap-tahap proses perawatan yang diberikan kepada pasien. Dokumentasi asuhan keperawatan merupakan catatan penting yang dibuat oleh perawat baik dalam bentuk elektronik maupun manual berupa rangkaian kegiatan yang dikerjakan oleh perawat meliputi lima tahap yaitu: 1) pengkajian, 2) penentuan diagnosa keperawatan, 3) perencanaan tindakan keperawatan, 4) pelaksanaan/implementasi rencana keperawatan, dan 5) evaluasi perawatan.

2. Saran

Sebagai seorang perawat ataupun mahasiswa keperawatan dapat berkerja profesional dalam menjalankan tugas dan kewajiban sebagai seorang perawat yang ideal dan bertanggung jawab. Salah satu bentuk kegiatan keperawatan adalah dokumentasi keperawatan profesional yang akan tercapai dengan baik apabila sistem pendokumentasian dapat dilakukan dengan benar. Kegiatan pendokumentasia meliputi ketrampilan berkomunikasi, ketrampilan mendokumenasikan proses keperawatan sesuai dengan standar asuhan keperawatan.

\section{DAFTAR PUSTAKA}

Asmadi. (2008). Konsep Dasar Keperawatan. Jakarta : Penerbit Buku Kedokteran (EGC). Aswar, Sandra. 2014. Faktor Yang Mempengaruhi Efektifitas Pelaksanaan Pendokumentasian Asuhan Keperawatan Di Instalasi Rawat Inap Bedah Rumah Sakit Umum Daerah Andi Makkasau Parepare. Jurnal Ilmiah Kesehatan Diagnosis, 5(4), 460-466. 
Mangole.J.E,dkk. (2015). Hubungan Perilaku Perawat Dengan Pendokumentasian Asuhan Keperawatan di Cardiovaskular And Brain Center RSUP PROF.DR.R.D. KANDOU MANADO. e-Journal Keperawatan (e-Kp), 3(2), 1- 9.

Muryani., Pertiwiwati, E., \& Setiawan, H. (2019). Kualitas Pendokumentasian Asuhan Keperawatan Di Ruang Rawat Inap (Studi di RSUD Kalimantan Tengah). Nerspedia, 2(1), 27-32.

Noorkasiani. Gustina. R. Siti Maryam. (2015). Faktor-faktor yang Berhubungan dengan Kelengkapan Dokumentasi Keperawatan. Jurnal Keperawatan Indonesia, 18(1), 1-8.

Nursalam. (2012). Manajemen Keperawatan Aplikasi Dalam Praktik Keperawatan Profesional. Jakarta : Salemba Medika.

Rohita, Tita, Krisna Yetti. (2017). Peningkatan Kualitas Pelayanan Keperawatan Melalui Ronde dan Pendokumentasian. Dunia Keperawatan : Jurnal Keperawatan dan Kesehatan, 5(1), 50-55.

Setiadi. (2012). Konsep dan Penulisan Dokumentasi Asuhan Keperawatan Teori dan Praktik. Yogyakarta : Graha Ilmu.

Simamora, R. (2009). Dokumentasi Proses Keperawatan.

Simamora, R. H., Purba, J. M., Bukit, E. K., \& Nurbaiti, N. (2019). Penguatan Peran Perawat Dalam Pelaksanaan Asuhan Keperawatan Melalui Pelatihan Layanan Prima. JPPM (Jurnal Pengabdian Dan Pemberdayaan Masyarakat), 3(1), 25-31.

Sugiyati, Sri. (2014). Hubungan Pengetahuan Perawat Dalam Dokumentasi Keperawatan Dengan Pelaksanaannya di Rawat Inap RSI Kendal. Prosiding Konferensi Nasional Ii Ppni Jawa Tengah 2014, 298-307.

Tarigan, R., Handiyani, H. (2019). Manfaat Implementasi Dokumentasi Asuhan Keperawatan Berbasis Komputerisasi Dalam Meningkatkan Mutu Asuhan Keperawatan. Jurnal Ilmiah Kesehatan Pencerah, 8(2), 110-116.

Wirawan, Emanuel Agung, dkk. (2013). Hubungan Antara Supervisi Kepala Ruang Dengan Pendokumentasian Asuhan Keperawatan Di Rumah Sakit Umum Daerah Ambarawa. Jurnal Managemen Keperawatan, 1(1), 1-6. 